TOMASZ MICHALEWSKI ${ }^{1}$

\title{
TOŻSAMOŚĆ NARODOWA A PROBLEM „POLSKOŚCI" I „ŚLĄSKOŚCI” W TWÓRCZOŚCI JANA GOCZOŁA
}

Słowa kluczowe: Jan Goczoł, tożsamość narodowa, patriotyzm, Śląsk Opolski

Zjawisko tożsamości jest przedmiotem rozważań w ramach różnych nauk społecznych: filozofii, psychologii, socjologii, antropologii i pedagogiki. Na gruncie humanistyki pojęcie to jest ściśle związane z refleksjami o człowieku. Termin "tożsamość” pojawił się na płaszczyźnie nauk społecznych w latach 50. XX wieku, a wprowadził go do dyskursu socjologicznego Erik Erikson, kontynuator teorii postfreudowskiej. Tożsamość to nasze wyobrażenie dotyczące tego, kim jesteśmy: kim jesteśmy jako zbiorowość, kim jestem jako jednostka. Ani pierwsza, ani druga nie jest nam dana raz na zawsze, jest dynamiczna: rozwojowa i zmienna. Ponadto proces jej kształtowania przebiega niejednakowo $w$ różnym czasie, ma też momenty bardziej i mniej znaczące.

Pojęcie tożsamości narodowej wykorzystywane jest, szczególnie w ostatnim okresie, przez wielu badaczy w różnych dziedzinach nauki. Zaznaczyć jednak trzeba, że rozumienie tego pojęcia jest bardzo niejednolite, stosuje się też wymiennie takie terminy, jak „tożsamość narodowa”, „identyfikacja narodowa”, „więź narodowa” czy „poczucie tożsamości narodowej”.

Poczucie tożsamości narodowej można rozumieć jako element struktury Ja, będący krańcowo subiektywnym symptomem świadomości narodowej. Subiektywizm w tym przypadku trzeba traktować jako swoistą wartość tego konstruktu, a jego uzasadnienia szukać w samym rdzeniu

\footnotetext{
${ }^{1}$ Dr; Uniwersytet Opolski; ORCID: 0000-0001-5503-2606; tmichalewski@uni.opole.pl.

2 J. Kosowska-Rataj, Studenci Opola. Studium tożsamości narodowej, Opole 1998, s. 28.
} 
humanistycznego podejścia w metodologii nauk społecznych. Psychologowie zauważyli, że ludzie skłonni są opisywać siebie za pomocą tych wymiarów, które są dla nich charakterystyczne. Zarazem jednak badania wykazują, że nasze schematy Ja tworzone są wokół tych jego wymiarów, które odróżniają nas od innych lub odnoszą się do tych dziedzin, w których możemy się z innymi porównywać3.

Interesującą propozycję teoretycznego ujęcia problemów tożsamości narodowej stanowi przedstawiony przez Antoninę Kłoskowską model analizy identyfikacji narodowej ze względu na emocjonalne przyswojenie kultury (walencję). Na pojęcie tożsamości narodowej składają się nie tylko zjawiska związane z kanonicznym centrum kultury, lecz także zbiorowa samowiedza (np. stereotypy). Wedle autorki naród to szeroka i złożona wspólnota komunikowania, wyobrażona i realizowana przez kulturę. W świetle własnych badań oraz materiałów autobiograficznych Kłoskowska postawiła tezę, że często jednoznaczność przepisana do jednej wyłącznie kultury narodowej jest problematyczna4.

Paweł Boski sprowadza pojęcie tożsamości narodowej do tożsamości społecznej. Musi ona spełniać warunki konieczne, jakimi są atrybuty kryterialne (symbole kulturowe), na które składają się wiedza, znaczenie osobiste, ewaluacja, przynależność do grupy, oraz atrybuty korelatywne, tj. wartości kulturowe pozwalające na socjalizację i internalizację oraz zbieżność Ja z prototypami ${ }^{5}$.

Tożsamość narodowa najpełniejszy wyraz znajduje w ideach narodu oraz w patriotyzmie związanym z traktowaniem ojczyzny jako najwyższej wartości. Myśl tę podejmował w swoim wystąpieniu Kardynał Stefan Wyszyński, mówiąc między innymi:

Jesteśmy świadomi prawdziwej ciągłości dziejowej, jaka istnieje między przeszłością, poprzez teraźniejszość, ku przyszłości. Jesteśmy pełni szacunku dla naszych uczonych, historyków, architektów, badaczy przeszłości historycznej Narodu i konserwatorów, którzy z pietyzmem podejmowali każdy ocalały relikt

${ }^{3}$ S.T. Fiske, M.A. Pavelchak, Reakcje afektywne oparte na przetwarzaniu kategorialnym a reakcje afektywne oparte na przetwarzaniu analitycznym. Rozwinięcie $w$ terminach koncepcji schematów wyzwalajqcych afekt, [w:] Poznanie, afekt, zachowanie, red. T. Maruszewski, Warszawa 1993, s. 113.

${ }^{4}$ A. Kłoskowska, Kultury narodowe u korzeni, Warszawa 2005, s. 103-112.

${ }^{5}$ P. Boski, M. Jarymowicz, H. Malewska-Peyre, Tożsamość a odmienność kulturowa, Warszawa 1992, s. 71-94. 
i szukali właściwego umiejscowienia go. To wszystko świadczy o tym, że Naród nasz, ciągle jeszcze niezwykle młody, nie zestarzał się w swojej dziesięciowiekowej drodze. Mądry Naród pochyla się dzisiaj z czcią nad swoją przeszłością. Tym więcej, że wstydzić się jej nie potrzebuje, chociaż wiemy, że jak w życiu ludzkim wiele można poprawić, tak w życiu Narodu wiele można było lepiej wykonać. Ale dziękujemy Bogu za taką przeszłość, szanujemy ją, nie chcemy z nią zrywać, przeciwnie, widzimy $w$ niej żywe powiązanie z teraźniejszością. Nasze współczesne prawa, wymagania i nadzieje wiążą się ściśle z dziejową przeszłością Narodu Tysiąclecia. W tym poczuciu szlachetnej miłości i czci ku przeszłości stajemy dziś tutaj [...], patrząc pogodnie i ufnie przez wieki przeżyte, ku przyszłości, której pragniemy innej, lepszej, pełnej pokoju i sprawiedliwości ${ }^{6}$.

Problem tożsamości narodowej jest szczególnie ważny i ciekawy, gdy mowa o Opolszczyźnie. Jest ona specyficznym regionem pod względem geograficznym i historycznym, pod względem tradycji kulturowej i struktury ludności. Opolskie to ziemia pograniczna, o burzliwych, bardzo bogatych dziejach, wielokulturowym dziedzictwie, rzadko spotykanym $w$ innych regionach. Panowali na niej Piastowie, królowie czescy, austriaccy, Habsburgowie, Prusacy, Niemcy. Po drugiej wojnie światowej mieszkańcy obecnej Opolszczyzny wraz z resztą Śląska znaleźli się w Polsce. Od 1945 roku Śląsk Opolski należy do Polski, przy czym wobec mieszkańców zastosowano specyficzną procedurę weryfikacji narodowościowej, w ramach której musieli udowodnić swą polskość lub związek z kulturą polską. Połączenie starej ziemi piastowskiej z Macierzą nastąpiło w lutym 1945 roku, kiedy to wojska Frontu Ukraińskiego i II Armia Wojska Polskiego przyniosły Opolszczyźnie upragnioną wolność. Mimo wyjątkowych trudności powrót Śląska Opolskiego do Macierzy przebiegał dość sprawnie. W krótkim czasie stworzono organy polskiej władzy, przeprowadzono złożoną akcję weryfikacyjną, ulokowano znaczną liczbę ludności przesiedleńczej, dokonano podziału granic, a życie polityczne zabarwiono polskością.

Przegrana druga wojna światowa spowodowała konieczność poszukiwania ostatecznej identyfikacji przez Ślązaków. Wielu z nich przy tej okazji przekonywało się, że choć przed wojną nie byli dość „niemieccy”, aby ich powszechnie uznawano za Niemców, to po wojnie ich odmienność kulturowa wyrażająca się między innymi w "skażonej” niemczyzną gwarze dyskwalifikowała ich jako Polaków i sprawiała, że jako „niepewny element” ciągle byli narażeni na praktyki dyskryminacyjne.

${ }^{6}$ S. Wyszyński, Jedna jest Polska. Wybór z przemówień i kazań, Warszawa 1989, s. 45. 
Ślązacy są grupą pograniczną i to nie tylko w sensie położenia fizycznego, ale także - przede wszystkim - kulturowo. Dostrzegał to ksiądz Emil Szramek, gdy pisał o "narożnikowym” charakterze Śląska. Jego zdaniem w regionie mieszka „lud opuszczony jak na wyspie, ale jednak tak zrośnięty z sercem narodów sąsiednich"7. Podobnie postrzegali Opolszczyznę po drugiej wojnie światowej badający ją uczeni, tacy jak Antonina Kłoskowska Stanisław Ossowski, Teresa Sołdra-Gwiżdż, Zofia Staszczak, Maria Śmiełowska.

Kształtowanie się tożsamości narodowej jest procesem historycznym, złożonym, bardzo żywotnym, podlegającym stale ewolucji, zdeterminowanym różnymi warunkami. Dlatego też badania nad nim należy prowadzić na różnych poziomach i różnymi metodami. Szerzej o tej kwestii pisała między innymi Anna Szyfer.

Z powyższymi uwagami korespondują także wypowiedzi Zbigniewa Kurcza na temat ludności rodzimej Śląska Opolskiego. Zasadniczą wątpliwością badacza jest, czy ludność rodzima Śląska Opolskiego to zamieszkali od dawna zasiedziali już Polacy, czy też przybysze z państw obszaru niemieckiego „których długotrwałe już współżycie doprowadziło już do ukształtowania odrębnej kultury i powstania nowej wspólnoty"9.

Pozostaje bowiem wątpliwość co do zasadności uznania wspomnianych mieszkańców za zwartą grupę etniczną czy też raczej grupy kulturowe niemające poczucia wspólnego pochodzenia. Biorąc pod uwagę złożone dzieje ziemi śląskiej, a także różne migracje ludności, wydaje się słuszne mówić o kilku grupach kulturowych.

Ziemia opolska wydała na świat ludzi wielkich pod względem przekonań i dążeń, postaw patriotycznych i żarliwości w działaniu. Łączyła ich miłość do ojczyzny, głębokie poczucie tożsamości narodowej i zakorzenienie w rodzimym, regionalnym środowisku.

W ich poczet można włączyć także tych, którzy swój patriotyzm, przywiązanie do regionu wyrażali w inny sposób. Taką właśnie wartą ocalenia od zapomnienia sylwetką jest Jan Goczoł, którego poezja, a także publicystyka bez reszty przesiąknięta jest autentycznym przywiązaniem do Śląska, jego historii, kultury, gwary, obyczajów. Prócz tego nacechowana jest

${ }^{7}$ E. Szramek, Ślqqsk jako problem socjologiczny. Próba analizy, Katowice 1934, s. 7.

${ }^{8}$ A. Szyfer, Warmiacy - studium tożsamości, Poznań 1996.

${ }^{9}$ Z. Kurcz, Kształtowanie się niemieckiej mniejszości narodowej na Ślq̨sku, „Kultura i Społeczeństwo" 1991, nr 2, s. 74. 
emocjonalnie pojętymi motywami śląskimi i nawiązuje do kultury wielu pokoleń mieszkających tu Polaków.

Bieg życia poety rozpoczął się 13 maja 1934 roku w Rozmierzy koło Strzelec Opolskich w rodzinie chłopskiej. Swoją ziemską wędrówkę zakończył 22 lutego 2018 roku. Był synem Józefa i Emilii z domu Gawlik. Pokolenie przyszłego poety musiało przeżyć (lata 30 .) wojenne dzieciństwo, stalinowską młodość i w rezultacie kilka etapów ułudnych nadziei, które nigdy się nie spełniły. Urodzić się zaś na Śląsku Opolskim oznaczało mieć niemieckie pochodzenie i w pokonywaniu życiowych perturbacji umiejętność liczenia wyłącznie na własne siły.

Przywiązanie serdeczne do Śląska - pisze o Goczole Adam Wierciński - do ludzi i spraw Śląska dotyczących, właściwie „opętanie” Śląskiem, szlachetna choroba, ciągle ponawiane próby zrozumienia istoty śląskości, śląskości jako przekleństwa i błogosławieństwa, (niemal) „miłość dwuskrzydlata”, o której dawno temu pisał Cyprian Norwid. Stary Ślązak, postać poetycka, złożona z okruchów rzeczywistości, czasem więcej rozumie i czuje niż autorzy pisujący grube księgi historyczne, socjologiczne, ludoznawcze. Mówi inaczej. Rozumie, czuje, kocha, nienawidzi, dziwi się, złości, z czasem traci cierpliwość, cedzi przez zęby, przychodzi z zaświatów nawet, by się upomnieć o swoją prawdę, mówi szeptem, a czasem już tylko do siebie. Społecznik homo politicus. Sensualista i myśliciel. Czuły na uroki życia i ciągle poszukujący prawdy ${ }^{10}$.

Goczoł swoją edukację zaczynał od niemieckiej szkoły. Po latach wspominał:

Ale moim językiem pierwszym, językiem domowym, językiem i matki, i ojca, była śląska gwara, z punktu widzenia dialektologii - tak zwana gwara kobylorzy, mieszkańców okolic Góry św. Anny i powiatów strzeleckiego oraz toszecko-gliwickiego, polska gwara śląska. To był - jak każda gwara - język mówiony.

${ }^{10}$ A. Wierciński, Jan Goczot, [w:] A. Wierciński, Głowy opolskie, Opole 1999, s. 40. Na temat życia i twórczości Goczoła wypowiadało się wiele osób - zob. m.in.: J. Goczoł, Poeta zawsze jest w drodze [Rozmawia Beata Szczerbaniewicz], „Nowa Trybuna Opolska” 1994, nr 87, s. 8-9; J. Neuberg, Ten mężczyzna kiedyś był mnq, „Opole” 1988, nr 5, s. 11-13, 22; D. Nowicka, Przywoływanie muz, „Nowa Trybuna Opolska” 1996, nr 53, s. 14; Współcześni polscy pisarze i badacze literatury. Słownik bibliograficzny, t. 3, red. J. Czechowska, A. Szałagan, Warszawa 1994, s. 64-65; K. Kossakowska-Jarosz, Reportaże z podróży po obrazach i wspomnieniach o ślq̨skiej Arkadii spisane przez Jana Goczoła na brzozowej korze, „Kalendarz Opolski" 2001, s. 206-207; Czasem bywam poetq [Z Janem Goczołem rozmawia Danuta Nowicka], „Nowa Trybuna Opolska” 7 V 2004, s. 21. 
Ale polskich liter - nieistniejących w alfabecie niemieckim, jakiego uczyliśmy się w szkole i jakim drukowane były podręczniki - uczyła mnie jeszcze podczas wojny nasza starka, babcia, z przechowywanych przez nią w ukryciu głęboko pod łóżkiem egzemplarzy wychodzącego na Górze św. Anny do 1913 roku „Głosu św. Franciszka” oraz wydanego w 1844 roku w Brzegu „Żywota wszystkich świętych”. To, być może, były prapoczątki moich fascynacji językowych, urzeczeń znaczeniem, a potem i pochodzeniem słów. A kiedy po przejściu frontu i naszych szkolnych „wielkich wakacjach” (między ostatnim dniem w szkole niemieckiej a pierwszym dniem w szkole polskiej) nowy kierownik szkoły zorientował się, że zaskakująco dobrze radzę sobie z czytaniem po polsku zaczął mi przynosić ze swojej domowej, a wkrótce już i z zaczątków szkolnej biblioteczki wciąż nowe książki. Połykałem zachłannie jedną po drugiej, wciąż nienasycony, wciąż rozpalony ciekawością następnej ${ }^{11}$.

Ten sielankowy obraz z czasem przeszedł do sfery mitu, rzeczywistość okazała się okrutna. Niczym romantyczny bohater czuł się poeta „odarty” z „kraju dzieciństwa”, co sprawiało, że przeżywał kryzys świadomości, utratę wiary w sens życia. Obrazy rujnowanej i milczącej już materii wzmagały w jego „ja wewnętrznym” zniechęcenie, „śmiertelny” strach, apatię i nade wszystko poczucie winy. Jednakże ów destrukcyjny proces miał swoje indywidualne i zbiorowe racje. Goczoła nie opuszczało bowiem przeświadczenie, że wszystko, co niszczy region i żyjących w nim ludzi, zarazem ma moc odradzającą, a więc twórczą ${ }^{12}$.

Po zdaniu matury w roku 1953 Jan Goczoł planował rozpocząć studia na Wydziale Dziennikarstwa Uniwersytetu Warszawskiego, jednakże „przeszkodziło" mu w tym sześciohektarowe gospodarstwo matki. Został zatrudniony jako księgowy w Państwowych Gospodarstwach Rolnych, najpierw na Dolnym Śląsku, potem na Śląsku Opolskim. Z tego - w owym czasie - mało stabilnego, a i mocno awanturniczego środowiska udało mu się po kilku miesiącach wyrwać poprzez przyjęcie propozycji pracy w Zarządzie Powiatowym Związku Młodzieży Polskiej w Strzelcach Opolskich. Ale i stąd po półtora roku wypłoszyło go, odczuwalne coraz mocniej, kostnienie organizacji. Przez pół roku pracował jako pomocnik maszynisty w transporcie kolejowym

11 Ślqaskowizna [Z poetą, publicystą i działaczem społecznym Janem Goczołem rozmawia Marian Buchowski], „Śląsk” 2009, R. XV, nr 163, s. 35.

12 Por. K. Kossakowska-Jarosz, Topos arkadyjski w twórczości Jana Goczoła, „Literatura Ludowa" 2005, nr 1, s. 11. Por. M. Piwińska, Człowiek i bohater, [w:] Problemy polskiego romantyzmu, seria 2, red. M. Żmigrodzka, Wrocław 1974, s. 57 i in. 
Śląskich Zakładów Przemysłu Wapienniczego, następnie został zatrudniony na stanowisku kierownika magazynów technicznych w fabryce obuwia.

W tym czasie Goczoł ujawnił temperament działacza społecznego i organizatora życia publicznego - w rodzinnej wsi prowadził amatorski zespół teatralny oraz Ludowy Zespół Sportowy. Pisał też swoje pierwsze wiersze na razie na użytek miejscowych amatorskich przedstawień teatralnych.

Poetycki debiut prasowy Goczoła miał miejsce w Opolu, w wychodzącym wówczas miesięczniku młodzieżowym „W marszu”. Wiosną 1956 roku ogłosił tam wiersz Ludwik van Beethoven. Kilka miesięcy później, jesienią, został powołany do odbycia służby wojskowej. Pełnił ją w pułku piechoty - i stamtąd do „Żołnierza Ludu” wysyłał swoje wiersze, a także pierwsze próby publicystyczne. Po pół roku przeniesiono go do redakcji tej gazety we Wrocławiu, będącym w tym czasie bardzo silnym ośrodkiem młodoliterackim - dla Goczoła był to pierwszy „czas zbierania doświadczeń wielkomiejskich". Ukończywszy w roku 1958 służbę wojskową, zdecydował się powrócić do rodzinnej Rozmierzy, która zawsze będzie dla niego nosiła znamię arkadii.

Przez pół roku pracował w opolskim Klubie Międzynarodowej Prasy i Książki, dojeżdżając codziennie z odległej o przeszło trzydzieści kilometrów Rozmierzy. Po nagłym pojawieniu się trudności dojazdowych powrócił do "swojej” "przedwojskowej” strzeleckiej fabryki obuwia, tym razem na stanowisko kalkulatora w dziale pracy i płacy.

Dwa lata później, w 1960 roku, ożenił się z Małgorzatą Witoń (z którą ma dwie córki) i - za namową przyjaciół - zdecydował się, siedem lat po maturze, podjąć studia polonistyczne w Wyższej Szkole Pedagogicznej w Opolu, gdzie od 1961 roku zamieszkiwał. Studiuje w trybie stacjonarnym, równocześnie - aby utrzymać rodzinę (żona po urodzeniu córki przestała pracować zarobkowo) - podejmuje różne popołudniowe i wieczorowe prace zlecone, między innymi prowadzi przez jakiś czas czytelnię Wojewódzkiego Domu Kultury. Rozpoczyna też stałą współpracę z miejscowym dziennikiem, „Trybuną Opolską", zamieszczając na jego łamach felietonowe impresje literackie w kilku cyklach - najpierw jako Zapiski z wioski rodzinnej, potem jako Kartki znad Ronda, Od soboty do soboty, wreszcie - pod nazwą Półwieś.

Jest to także czas dużej aktywności poetyckiej Jana Goczoła. Jego wiersze zaczynają się ukazywać w centralnych czasopismach literackich, m.in. w „Odrze”, „Poglądach”, „Tygodniku Kulturalnym”, „Życiu Literackim”, „Miesięczniku Literackim”, „Poezji”. 
W tym okresie poeta zaczyna uczestniczyć w ruchu młodoliterackim. Działają tutaj również Stanisław Danecki, Wiesław Kazanecki, Wiesław Koszela, Bogdan Loebl, Irena Wyczółkowska czy Bogusław Żurakowski. Jest też współzałożycielem opolskiej grupy literackiej „Formaty”, zaś nieco później należy do inicjatorów powołania ośrodka Korespondencyjnego Klubu Młodych (pisarzy), jednego z pierwszych w kraju. W 1962 roku Jan Goczoł zostaje przyjęty do Związku Literatów Polskich.

Pięcioletnie studia polonistyczne, zakończone pracą magisterską o tytule "Nowe kierunki w poezji dla dzieci w dwudziestoleciu 1945-1965", były dla Jana Goczoła przede wszystkim wielką przygodą językoznawczą. Wyrosły z gwarowej świadomości językowej, a właściwie nadal głęboko w niej zakorzeniony, w języku - zarówno w jego konstrukcjach gramatycznych, jak i w zasobach leksykalnych, frazeologii, składni i metaforyce - odkrywa nieznane mu dotąd pokłady bogatej polszczyzny. Studia na wyższej uczelni jako przebijanie się „z Rozmierzy w świat” nie były tym samym wolne od różnych obciążeń tradycją, kompleksami kulturowymi i narodowościowymi „hanysa”.

Pierwszą po studiach pracę dziennikarską otrzymuje Goczoł w katowickich „Poglądach” redagowanych przez Wilhelma Szewczyka. Rezygnuje z zamierzonej uprzednio pracy nauczyciela wiejskiego w szkole rolniczej. Pięcioletni okres katowicki (1965-1970) - Goczoł dojeżdża z Opola - poeta określa jako kluczowy dla ukształtowania się jego śląskiej samoświadomości. Krąg współpracowników i przyjaciół „Poglądów” - dziennikarzy, pisarzy, artystów plastyków, aktorów, filmowców, działaczy społecznych i politycznych, górników, powstańców śląskich - tworzył jedyną w swoim rodzaju wszechnicę przeszłości i współczesności Śląska.

Działalność redaktorska, aczkolwiek najbardziej odpowiadająca temperamentowi pisarza, jest jednakże tylko jedną z form aktywności społecznej Goczoła. Równolegle działa w miejscowych organizacjach kulturalnych, zwłaszcza w Opolskim Towarzystwie Kulturalno-Oświatowym. Organem tego towarzystwa było czasopismo „Wczoraj - Dzisiaj - Jutro”, z którym poeta ściśle kooperował, przez szereg lat zasiadając w jego redakcji. Przez kilka lat współredaguje wydawane przez towarzystwo, a mające świetne tradycje „Kalendarze Opolskie”, współpracuje z galeriami wystawienniczymi Biura Wystaw Artystycznych oraz Klubu Związków Twórczych. Pięć lat jest konsultantem literackim $w$ opolskim Teatrze im. Jana Kochanowskiego, a przez dziesięć lat prezesuje opolskiemu Oddziałowi Związku Literatów Polskich, organizując między innymi ważne dla życia literackiego Opolskie Dni Literatury. 
Na łamach „Trybuny Opolskiej” drukował w odcinkach swoje Zapiski $z$ wioski rodzinnej. Uprawiał także prozę i publicystykę.

Dostrzeżony został i talent poetycki Jana Goczoła. Należy on do poetów nagradzanych i wyróżnianych. Niewątpliwie najbardziej prestiżowymi wyróżnieniami są tutaj: Nagroda Literacka im. Stanisława Piętaka (1974), Nagroda Ministra Kultury i Sztuki I Stopnia (1985), Nagroda im. Karola Miarki (1995), Nagroda Prezydenta Miasta Opola za wybitne osiągnięcia w dziedzinie kultury (1997). Ten nagradzany za własną twórczość poeta para się również tłumaczeniami: z niemieckiego przekładał $m$.in. wiersze Volkera Brauna, z rosyjskiego - Aleksandra Plitczenki, z macedońskiego Atanasa Vangełowa. Sam także był tłumaczony (na angielski, bułgarski, czeski, niemiecki, rosyjski) i drukowany w periodykach i antologiach za granicą. Warto jeszcze odnotować, iż w 1989 roku został członkiem Zarządu Głównego ZLP13.

Już pierwszy kontakt z poezją Goczoła budzi zrozumiałe zaskoczenie i zdziwienie. Przyczyną jest poważna liczba dokonań literackich, ich różnorodność, a nade wszystko wysoki poziom artystyczny. $W$ jego twórczości spotykamy utwory o dużej rozbieżności wątków tematycznych, a także odmienności formalnej. Widzimy tutaj niemal wszystkie dobrze zakotwiczone w tradycji polskiej poezji formy wypowiedzi lirycznej. Są wiersze posługujące się liryką wyznania - mamy tu ulotne przeżycia, wspomnienia, rozterki, tęsknotę, a jednocześnie urok prostoty, świeżość, liryzm. Charakterystyczną odmianą tej poezji są erotyki, które także spotykamy w twórczości Goczoła. Sporo można też podać przykładów liryki filozoficznej, podejmującej takie tematy, jak tajemnica życia i śmierci, paradoksy ludzkiego losu czy zaduma nad istnieniem i sensem życia. Twórca uprawia także lirykę pejzażową - mamy tu przykłady pejzażu wiejskiego, urbanistyczne obrazki rodzajowe, opisy śląskiej przyrody. Czasem pisze wiersze o charakterze pejzażowo-refleksyjnym. Ciekawą grupę stanowią utwory mówiące o twórczości poetyckiej. W niektórych strofach wspomnieniowych pojawiają się motywy dzieciństwa. Najważniejszą tematyką u Goczoła pozostaje jednak nobilitowanie, a niekiedy wręcz sakralizowanie motywu Śląska. Śląskość widzi on często w rekwizytach zwykłych, prozaicznych, z gruntu mało poetyckich.

${ }^{13}$ Biogram został opracowany na podstawie następujących prac: L. Pośpiechowa, Pisarze Opolszczyzny, Opole 1975; J. Goczoł, Poezje wybrane, wybór i wstęp autora, Warszawa 1985; J. Neuberg, Jan Goczoł, Opole 1998; Współcześni pisarze Opolszczyzny - informator, oprac. H. Jamry, V. Łabędzka, Opole 1999. 
W jego poezji znajdziemy ciekawe metafory, obrazy czy symbole, jak w wierszu Stary Ślqzak, którego nie było:

$$
\begin{gathered}
\text { Myślałem, że on już w zaświatach, że uwolniony jest } \\
\text { z kaftana bezpieczeństwa narodowościowej opcji, } \\
\text { myślałem, że u Pana Boga za piecem dożywa } \\
\text { zasłużonej wieczności. Jednakże coraz to } \\
\text { płatni posłańcy płatnych słuchaczy głośno przekonują } \\
\text { o nieprawidłowości tego, co było. Starego Ślązaka } \\
\text { z rejestru przodków pospiesznie wymazują, } \\
\text { tak jakby nigdy nie był żył. }
\end{gathered}
$$

(Zapisy śladowe, s. 27)

W swojej twórczości Goczoł - zauważa Krystyna Kossakowska-Jarosz nie tylko podejmuje tematy dla tego miejsca ważne, lecz także jest wierny aurze rodzinnej przestrzeni, lokalnemu kolorytowi, tutejszemu sposobowi myślenia i wyrażania. Inna problematyka, zgodnie z tym, co deklarował sam autor, miała być jedynie „azylem dla wyobraźni”, „śpiewem uzdrawiającym duszę chorego" - za jakiego uważał się poeta bolejący nad "niemotą wyspy rozmywanej zdobywczym żywiołem", jak nazywał swój region. Śląsk i Ślązaków utożsamiał on bowiem z "czarnymi dziurami naszej polskiej współczesności". Doszedł do tego wniosku w następstwie przekonania, że „To, co o materii śląskości się mówi, co się pisze, co się do wierzenia podaje, to - podobnie jak w odniesieniu do rzeczywistych czarnych dziur w kosmosie - hipotezy i domysły", choć zaznaczał, iż szukając argumentów, pomijał „wyobrażenia czytankowo naiwne i dydaktyczne, [...] wypowiedzi intencjonalne, tendencyjne, [...] fałszerstwa"14.

Jaki jest więc ten Goczołowy Śląsk? Jego istota wydaje się - jak pisze Jan Neuberg ${ }^{15}$-zamykać w tak budujących i stanowczych spostrzeżeniach, jak choćby to:

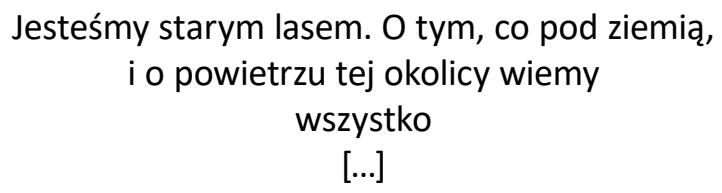

${ }^{14}$ K. Kossakowska-Jarosz, Jana Goczoła literatura nurtu regionalnego, [w:] Człowiek i czas. Studia i szkice o literaturze współczesnej, red. E. Dąbrowska, A. Pryszczewska-Kozołub, Opole 2002, s. 246-247. Por. J. Goczoł, Słowo od Autora, [w:] Poezje wybrane, op. cit., s. 11-12, 16.

15 J. Neuberg, Jan Goczot, Opole 1998, s. 35-36. 
Oko Boże widzi, ucho Pana słyszy

być może więcej. Na przykład nasze dawne czasy, naszą pamiętliwość.

(Poezje wybrane, s. 136)

Istota dzisiejszego Śląska w rozumieniu Goczoła - kontynuuje swe rozważania przywołany krytyk - tkwi, niestety, także w czym innym, znacznie mniej budującym. Wyraża ją poetycki sprzeciw wobec wszelkich prób zawładnięcia tą ziemią i świadomością jej mieszkańców. Niepokojem napawać muszą słowa i wymowny gest milczenia Starego Ślązaka:

Nasze narzecze jest pociemniałe i twarde Jak drewno, które długo leżało pod wodą.

W naszym narzeczu mówimy niewyraźnie i

Cicho, bowiem języki nasze są podcięte.

Nasze narzecze rozumie Pan Bóg, a także Śmierć - czujemy to wieczorami, przed zaśnięciem.

(Poezje wybrane, s. 138)

Stary Ślązak milczy, tak jak milczy woda W cembrowanej studni. Co na dno opadło, Kamieniami zarosło. $Z$ czego w ustach gorycz.

Już za niego dawno inni wszystko mówią, Sam by nie pomyślał, że tak trzeba mówić. Już mu do milczenia nie zostało długo.

(Poezje wybrane, s. 139)

„Jeszcze jeden problem rozwiązuje się sam z siebie. [...] Stary Ślązak niczym już nie wadzi" - czytamy w wierszu pt. Stary Ślqzzak umiera. W zasadzie dość często - zauważa Neuberg - poprzestaje poeta na tego rodzaju gorzko-ironicznych konstatacjach. Jakby nie leżało $w$ jego mocy rozpoznanie mechanizmów owego tragicznie „samoistnego” rozwiązywania się problemów Ślązaka i Ślązaków, jakby już pogodził się z rolą płaczki ${ }^{16}$.

Stary Ślązak to motyw niezwykle częsty w poezji Goczoła, widoczny w takich wierszach, jak Stary Ślq̨zak mówi, Stary Ślq̨zak milczy, Stary Ślqzak

${ }^{16}$ Ibidem, s. 35-37. 
na rocznicę, Stary Ślqzak umiera, Stary Ślq̨zak w niebie. To jakby porte-parole samego poety. W słowie wstępnym do tomiku Zapisy śladowe Jan Neuberg trafnie zauważa: „Goczołowy Stary Ślązak jest postacią znakomicie wykreowaną, i ma szansę stać się literackim mitem". Trzymając się konwencji "Starych Goczołowych Ślązaków”, powiedzmy o poecie: Ślązak z Rozmierzy pisze wiersze. Upoważnia nas do tego przekonanie, iż ten wybitny współczesny opolski poeta utożsamia się ze swymi Starymi Ślązakami. I tymi z jego rodzinnej Rozmierzy, i tymi z innych śląskich wsi, miasteczek i miast, którzy są stąd i którzy są solą tej ziemi ${ }^{17}$. Na temat Starego Ślązaka interesująco wypowiadał się zresztą sam Jan Goczoł na łamach czasopisma „śląsk":

„Niewidzialny, ale jest”, tak teraz o nim piszę. Jako niewidzialnie realny może być i mną, i moją wyobraźnią o sobie, ale i kimś z moich namiętnych pragnień o wymierzeniu sprawiedliwości fałszom w naszym życiu - on byłby wtedy tym koronnym, nieprzekupnym świadkiem tego wszystkiego, czego tutaj, na Śląsku, doświadczyłem, w co uwierzyłem i wierzę. To pragnienie-marzenie o takim świadku coraz to go przywołuje, a on w milczeniu, zda się, na to przystaje. I wciąż jeszcze czeka na swoje „ostatnie słowo” przed sprawiedliwym trybunatem $\mathrm{Czasu}^{18}$.

Kreacja Starego Ślązaka - jego świadomości - najlepiej pokazuje nastawienie poety do dawnych i obecnych spraw małej ojczyzny. Oto wiersz pt. Stary Ślq̨zak chodzi:

\author{
Usłyszałem kroki. Obudziły mnie ze snu \\ w środku nocy. Rozpoznałem je wyraźnie \\ od pierwszego stąpnięcia. Stary Ślązak chodził \\ po swoim obejściu. \\ Z miejsca na miejsce szedł na pamięć. Od wielu lat, \\ może od stu już, tak chodzi. Z każdym rokiem \\ coraz więcej do zgarnięcia i do zamiatania \\ po tych ślinoustnych. \\ Że też Pan Bóg taki jest cierpliwy, myśli, \\ przecież widzi, co tu sieją. Kto jak kto \\ sprawiedliwiej zna te strony?
}

17 J. Szczupał, Ślqzak z Rozmierzy pisze wiersze, [w:] Almanach miejski „Opolanin 2000", red. K. Raczyńska, Opole 2000, s. 160.

${ }^{18}$ Ślqskowizna. Z poetq, publicystą..., op. cit., s. 37. 


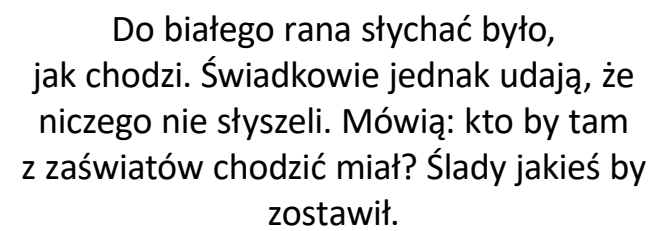

(Zapisy śladowe, s. 63)

We współczesnej literaturze polskiej - według Ryszarda Nycza - poszukiwania wzorców tożsamości małych ojczyzn można ująć w dwa dominujące typy. Pierwszy budowała strategia zadomowienia, która przede wszystkim legitymizowała ważny nurt racjonalno-etnocentryczny. Wyrażał się on $w$ charakterystyce regionalno-rustykalnej przyjmującej dwie mutacje: albo swoistej reakcji na dotkliwości życia nowoczesnego, albo rewindykacji praw prowincji wobec centrum. Drugiemu wariantowi tropów tożsamości kształt nadawała natomiast problematyka domowych "miejsc utraconych”, ujmowana w sposób nostalgiczny lub ironiczny. Dawna ziemia rodzinna traktowana była wówczas jako przeciwwaga dla aktualnych miejsc pobytu pisarzy przyjmujących znaki przestrzeni wykorzenienia i bezdomności. Dynamikę tego modelu fundowała fascynacja odkrywaniem osobliwości w swojskiej przestrzeni, inności w obrębie oswojonego terytorium, obcości we własnym domu, różnorodności w tym, co dotąd wyglądało nadzwyczaj jednorodnie, a z oddalenia jawiło się raczej jako plątanina obcych śladów, tradycji i zwyczajów. Doznawane olśnienia prowadziły do przewartościowania zwyczajowych więzi między człowiekiem a miejscem jego pobytu czy pochodzenia oraz do odnajdywania tradycyjnych wzorców we własnej tożsamości ${ }^{19}$.

Jan Goczoł jako spadkobierca śląskości, ale także jako jej krytyk, obserwator i uczestnik - zauważa Kossakowska-Jarosz - regionalnej teraźniejszości prowadzącej do uprzedmiotowienia ziomków, w znakach afirmowanej wiejskiej przeszłości (utożsamianej z górnośląską obyczajowością) będzie szukał języka sensów wspólnoty Ślązaków. Zacznie się zatem w jego ocenie liczyć wszystko, co obowiązywało tutaj „przed laty”, a „dawne czasy" zawsze nazywać będzie tylko "czasami dobrymi” (Toast, 1969-1973). W kontekście tej metafory temporalnej szczególnej wagi nabierze zbiorowe

${ }^{19}$ K. Kossakowska-Jarosz, Topos arkadyjski..., op. cit., s. 5. Por. R. Nycz, Tropy „ja”. Koncepcje podmiotowości w literaturze polskiej ostatniego stulecia, [w:] idem, Język modernizmu. Prolegomena historycznoliterackie, Wrocław 1997; idem, Literatura jako trop rzeczywistości. Poetyka epifanii w nowoczesnej literaturze polskiej, Kraków 2001. 
trwanie przy dawnej tradycji i odwiecznych wartościach. W konsekwencji twórca stanie się apologetą „dawności”, dla której zagrożeniem w jego ocenie będą dwa czynniki. Po pierwsze, nietuzinkowo pojmowani "obcy" na tej ziemi, bowiem kryterium przynależności terytorialnej i więzi nawykowej podporządkuje on obywatelskiej świadomości kulturowej. Po wtórne, niszczące śląską krainę procesy cywilizacyjne - te, jak powie, „straszliwe siły ciążenia". Zacznie więc cierpieć na katastroficzne wizje przyszłych losów degradowanej śląskości, zbiorowe trwanie zaś w argumentacji autora stanie się czynnikiem aksjologicznym. Uzna on bowiem, że jednostka pozbawiona grupowego oparcia łatwiej może wejść w rolę apostaty. Renegata wobec tego pocznie obawiać się szczególnie mocno, troszcząc się zarazem, aby samemu się nim nie stać ${ }^{20}$.

Diagnoza Goczoła o stanie zachowania śląskości momentami nabiera wręcz katastroficznej charakterystyki. Pisarz niekiedy uważa, że Ślązacy, mimo wysiłków, nie należą już do żadnego świata: ani do tradycji i pamięci, ani do nowej cywilizacji. Stąd też u niego niepokojące motywy pustki, zaświatów czy śmierci ${ }^{21}$.

Z twórczości Jana Goczoła, „uwikłanej w śląskość”, w śląskocentryczne rozumowanie, można wyprowadzić wnioski o wartościach przydatnych w porozumieniu ludzi narodów. Krzewiąc wartości swego regionu, pisarz czyni z nich walor, dzięki któremu można uczestniczyć w dialogu kultur22.

Zamieszczone $w$ kilku tomikach wiersze są artystycznym, literackim świadectwem pulsu śląskiej ziemi i ludzi żyjących tu od pokoleń. Nie są to wiersze tylko pogodne. Nie ma w nich bukolicznej sielankowości i nostalgicznej rzewności. Nie ma gładkiego „krajoznawczego" opisu "jak to na śląskoopolskiej wsi ładnie”. Mowa Goczoła często jest „trudna”. Słowa niekiedy bolesne. Goczoł bowiem śledzi też niedobre zjawiska zachodzące w kulturze, w życiu społecznym - chciałoby się napisać w ,jestestwie" Śląska Opolskiego. Nie czyni tego jednak beznamiętnie, nie jest jedynie chłodnym obserwatorem z zewnątrz. Jest stąd. Z tej ziemi i o wszystkim mówi z głębokim zaangażowaniem i przejęciem ${ }^{23}$.

\footnotetext{
${ }^{20}$ K. Kossakowska-Jarosz, Topos arkadyjski..., op. cit., s. 8.

${ }^{21}$ Por. ibidem, s. 29.

${ }^{22}$ K. Kossakowska-Jarosz, Jana Goczoła literatura nurtu regionalnego, op. cit.,

${ }^{23}$ Por. J. Szczupał, Ślqzak z Rozmierzy..., op. cit., s. 159.
} s. $247-248$. 
„Kim więc jestem?” - to pytanie, gdy mowa o tożsamości. W poszukiwaniu kryteriów orzekania o czyjejś tożsamości psychologowie często odwołują się do subiektywnych odczuć, opisywanych, gdy jednostka konfrontowana jest z tym pytaniem i serią pytań o to, czy poczucie, że „ja to ja, a nie ktoś inny", utrzymałoby się, gdyby różne atrybuty osoby uległy zmianie czy bezpowrotnie zniknęły (jak w przypadku kalectwa, zmian związanych z wiekiem, przemieszczaniem się w świecie, podejmowaniem nowych ról społecznych itp. $)^{24}$.

Osobowość Jana Goczoła wpisuje się bez reszty w pejzaż kulturalny Opolszczyzny, a cechuje ją konsekwentne pielęgnowanie śląskiej tożsamości, co jest widoczne w całej jego twórczości. Śląskość ta przechodzi niekiedy w jego wierszach $w$ świat mitu, który uosabia Stary Ślązak:

3.

Stary Ślązak patrzy. Nikt by nie pomyślał, że on patrzy tam z dołu. Gdyby to wiedzieli, widłami by go.

Póki co woda cicha. Na powierzchni kumaki w politycznych monologach orgazmu bliskie

4. Stary Ślązak się śmieje, być może płacze. Któż tam wie - nic nie widać tam z góry.

(Zapisy śladowe, s. 45)

Twórczość poetycka Jana Goczoła, jednego z nielicznych już pełnych żarliwości obrońców rodzimej tradycji, nacechowana emocjonalnie motywami śląskimi, nawiązuje do kultury wielu pokoleń Ślązaków. Poetę niepokoją zagrożenia tożsamości śląskiej: różne przemiany społeczne, polityczne, obyczajowe czy kulturowe kładą się cieniem na tej „krainie” i jej mieszkańcach $^{25}$. Warto też zauważyć, że ciągle narastająca migracja wpływa negatywnie na postawy rodzinne Ślązaków, na ukształtowane przez wieki

${ }^{24}$ M. Jarymowicz, Tożsamość jako efekt rozpoznawania siebie wśród swoich i obcych, [w:] P. Boski, M. Jarymowicz, H. Malewska-Peyre, Tożsamość a odmienność..., op. cit., s. 214.

${ }^{25}$ Por. J. Neuberg, Jan Goczoł..., op. cit., s. 35. 
obyczaje, zwyczaje i świadomość narodową. Wszystko to dokonuje niewątpliwie erozji w poczuciu tożsamości Ślązaków.

Jan Goczoł wyrażał niepokoje związane z utratą przez Ślązaków tożsamości, która kształtowała się wiekami, a której utrata może się dokonać w jednym pokoleniu. We wspomnieniu pośmiertnym Jan Cofałka, były wiceprezes i sekretarz generalny Towarzystwa Przyjaciół Śląska w Warszawie, nazwał Goczoła ostatnim z wybitnych poetów z prawdziwą śląską duszą.

Jan Goczoł był bowiem jednym z niewielu twórców, którzy doskonale rozumieli naturę, mentalność, kulturę rodaków z małej ojczyzny i w sposób artystyczny oddali ją w poetyckich obrazach.

Przywołanie postaci i dorobku Goczoła przekonuje o jego roli w szerzeniu i gruntowaniu patriotyzmu regionalnego i tożsamości narodowej. Niniejsze uwagi potwierdzają również tezę, iż autentyczne zaangażowanie w działalność regionalną, przywiązanie do regionu, utożsamianie się z jego wartościami (tradycja, kultura, gwara) wzmacnia patriotyzm, przywiązanie nie tylko do „małej”, lecz także do „wielkiej” ojczyzny.

\section{BIBLIOGRAFIA}

Boski P., Jarymowicz M., Malewska-Peyre H., Tożsamość a odmienność kulturowa, Warszawa 1992.

Czasem bywam poetq [Z Janem Goczołem rozmawia Danuta Nowicka], „Nowa Trybuna Opolska" 7 V 2004.

Fiske S.T., Pavelchak M.A., Reakcje afektywne oparte na przetwarzaniu kategorialnym a reakcje afektywne oparte na przetwarzaniu analitycznym. Rozwinięcie $w$ terminach koncepcji schematów wyzwalających afekt, [w:] Poznanie, afekt, zachowanie, red. T. Maruszewski, Warszawa 1993.

Goczoł J., Poeta zawsze jest w drodze [Rozmawia Beata Szczerbaniewicz], „Nowa Trybuna Opolska" 1994, nr 87.

Goczoł J., Poezje wybrane, wybór i wstęp autora, Warszawa 1985.

Jarymowicz M., Tożsamość jako efekt rozpoznawania siebie wśród swoich i obcych, [w:] P. Boski, M. Jarymowicz, H. Malewska-Peyre, Tożsamość a odmienność kulturowa, Warszawa 1992.

Kłoskowska A., Kultury narodowe u korzeni, Warszawa 2005.

Kosowska-Rataj J., Studenci Opola. Studium tożsamości narodowej, Opole 1998.

Kossakowska-Jarosz K., Topos arkadyjski w twórczości Jana Goczoła, „Literatura Ludowa” 2005, nr 1. 
Kossakowska-Jarosz K., Jana Goczoła literatura nurtu regionalnego, [w:] Człowiek i czas. Studia i szkice o literaturze współczesnej, red. E. Dąbrowska, A. Pryszczewska-Kozołub, Opole 2002.

Kossakowska-Jarosz K., Reportaże z podróży po obrazach i wspomnieniach o ślqqskiej Arkadii spisane przez Jana Goczoła na brzozowej korze, „Kalendarz Opolski” 2001.

Kurcz Z., Kształtowanie się niemieckiej mniejszości narodowej na Ślq̨sku, „Kultura i Społeczeństwo" 1991, nr 2.

Neuberg J., Jan Goczot, Opole 1998.

Neuberg J., Ten mężczyzna kiedyś był mnq, „Opole” 1988, nr 5.

Nowicka D., Przywoływanie muz, „Nowa Trybuna Opolska” 1996, nr 53.

Nycz R., Literatura jako trop rzeczywistości. Poetyka epifanii w nowoczesnej literaturze polskiej, Kraków 2001.

Nycz R., Tropy "ja”. Koncepcje podmiotowości w literaturze polskiej ostatniego stulecia, [w:] R. Nycz, Język modernizmu. Prolegomena historycznoliterackie, Wrocław 1997.

Piwińska M., Człowiek i bohater, [w:] Problemy polskiego romantyzmu, seria 2, red. M. Żmigrodzka, Wrocław 1974.

Pośpiechowa L., Pisarze Opolszczyzny, Opole 1975.

Szczupał J., Ślqzak z Rozmierzy pisze wiersze, [w:] Almanach miejski „Opolanin 2000”, red. K. Raczyńska, Opole 2000.

Szramek E., Ślq̨sk jako problem socjologiczny. Próba analizy, Katowice 1934.

Szyfer A., Warmiacy - studium tożsamości, Poznań 1996.

Śląskowizna [Z poetą, publicystą i działaczem społecznym Janem Goczołem rozmawia Marian Buchowski], „Śląsk" 2009, R. XV, nr 163.

Wierciński A., Jan Goczoł, [w:] A. Wierciński, Głowy opolskie, Opole 1999.

Współcześni pisarze Opolszczyzny - informator, oprac. H. Jamry, V. Łabędzka, Opole 1999.

Współcześni polscy pisarze i badacze literatury. Słownik bibliograficzny, t. 3, red. J. Czechowska, A. Szałagan, Warszawa 1994.

Wyszyński S., Jedna jest Polska. Wybór z przemówień i kazań, Warszawa 1989.

\section{NATIONAL IDENTITY AND THE PROBLEM OF "POLISH" AND "SILESIA" IN THE WORK OF JAN GOCZOŁ}

Abstract: The article presents the issues of Polishness and Silesianness in the national consciousness of Jan Goczot, who is known as a poet with a great deal of authorship, prose writer, columnist, and also an Opolian Silesia cultural activist. The article describes the life path of the poet, his family background, and the crystallisation of national consciousness in his writing. The poetry of the defender of the native tradition is emotionally marked with Silesian motifs and refers to the culture of many generations of Silesians.

Keywords: Jan Goczoł, national identity, patriotism, Opolian Silesia 